ing the skin, in consequence of its being firmly attached to the diseased mass. The bleeding ressels being secured the edges were brought together, and the man did well. Upon cutting into the testicle after the operation, there was what appeared to be the nucleus of the disease, something resembling the kernel of a nut, with the epi. didymis encircling it. In all probability the integrity of the testicle having been destroyed, a new action was set up which produced such disastrous results.

\section{ACTION OF POISONS.}

\section{To the Editor of THE LANCET.}

Sir:-Yon will oblige me by correcting a slight error which has occurred in the report of my memoir "On the Action of Poisons," read before the Medical and Chirurgical Society on the 8 th inst. The error in question relates to the time required for a substance to pass from the jugular vein in the horse to the capillary terininations of the coronary arteries. In your report this is stated to be ten seconds, instead of sixteen seconds, which is the lime furnished we by my experiments, and which I believe to be that which I stated in my memoir. I remain your obedient servant,

7, Cork-street, Bond-street.

JAMES BLAKE.

\section{TO THE INDEPENDENT ELECTORS} OF THE

\section{BOROUGH OF FINSBURY.}

Gentlemen:-The pleasing duty again devolves upon me of expressing the deep and lasting feeling of gratitude that $I$ entertain for the distinguished honour which you have now, for the third time, conferred upon me, by electing me as one of your representatives in Parliament.

Words are by far too feeble to convey to your minds an adequate conception of my sense of the obligation which I owe to you, or of the vast responsibility of the trust which you have confided to my keeping. The only requital that $I$ can at this moment offer to you, is the assurance of my fixed determination faithfully and diligently to discharge $m y$ duty to you and to the people, in the same honourable and patriotic spirit which has influenced your own highminded and disinterested motives in the choice of your representatives. I have the honour to remain, Gentlemen, your grateful and devoted servant,

Thomas Wakley.

35, Bedford-square, Jaly 1, 1841.

\section{BOOKS RECEIVED.}

Catalogue of Plants collected in the Neighbourhood of Banbury. By George Gulliver, F.R.S., F.Z.S. London: Tilt and Co., 1841, 12mo., pp. 37.

On Stammering and Squinting, and on the Methods for their Removal. By Edwin Lee. Loudon: Churchill, 1841, 8vo., pp. 88. The Surgeon's Vade-mecum. By Robert Druitt. Second Edition. Illustrated with Fifty Wood Engravings. London: Renshaw and Churchill, 1841, 12mo., pp. 524.

A Practical Essay on some of the Principal Surgical Diseases of India. By F. H. Brett. Calcutta: Thacker and Co., 1840, 8 vo., pp. 506.

Practical Illustrations of the Treatment of Obstructions in the Urethra and other Canals by the Dilatation of Fluid Pressure: also an Essay on the Various Modes of removiug Urinary Calculus. By James Arnott, M.D. Londou: Churchill, 1841, 8vo., pp. 119.

A Report of the Cases attended at the Birmingham Eye Infirmary, during the Years 1838 and 1839. By Richard Middlemore, Esq., Surgeon to the Infirmary. Worcester: Deighton and Co., 1841, pp. 20.

The Retrospect of Practical Medicine and Surgery, being a Half-yearly Journal, containing a Retrospective View of every Discovery and Practical Improvement in the Medical Sciences. Edited by $W$. Braithwaite, M.R.C.S., Surgeon to the Leeds General Eye and Ear Infirmary, \&c. Vol.2. No. 3. January - June, 1841. London: Simpkin, Marshall, and Co. 1841.

\section{TO CORRESPONDENTS.}

We are requested to direct the particular attention of our readers to the advertisement which will be found on the cover of this week's Lancet, headed " Anniversary Meeting of the Provincial Medical and Surgical Assochation." The meeting will be held at York, in the first week of August next.

Communications have been received from Mr. Adumson; Mr. Clay; Medicus.

Mir. Clay's paper has been unfortunately misldid; the statement that it was in type must have been a mistake on the part of our publisher.

$\operatorname{Mr}$. Yeursley's communication is deferred this week from want of space.

Mr. Maxwell's paper has been received.

In the meeting of the medical practitioners of Marylebone in our last week's Number, $\boldsymbol{M}_{T}$. Hancorne's name should be substituted for R. Harrison.

Mr. Simpson's (Stamford) paper has been received; the request by which it was accompanied shall be attended to. 